Research Journal of Environmental and Earth Sciences 12(2): 10-18, 2020

DOI:10.19026/rjees. 12.6047

ISSN: 2041-0484; e-ISSN: 2041-0492

(C) 2020 Maxwell Scientific Publication Corp.

Submitted: February 6, 2020

Accepted: April 27, 2020

Published: August 25, 2020

\title{
Research Article \\ Paleoenvironments of Coniacian Age Outcrops in the Congo Coastal Sedimentary Basin
}

\author{
${ }^{1,2}$ Hilaire Elenga, ${ }^{1}$ Nehl Dorland Kobawila, ${ }^{2}$ Dieudonné Maurice Malounguila Nganga, \\ ${ }^{1}$ Timothée Miyouna and ${ }^{1}$ Princesse Zatonga \\ ${ }^{1}$ Département de Géologie, Faculté des Sciences et Techniques, Université Marien Ngouabi, Congo \\ ${ }^{2}$ Centre de Recherches Géologiques et Minières, Congo
}

\begin{abstract}
The study of the Turonian formations outcropping along the Congolese coast was undertaken in the order of to understand the sequential organization of the deposits as well as the evolution of the paleoenvironments. The study consisted of a detailed description of the lithofacies in the field and in the laboratory. This study shows that these formations are essentially made up of silty dolomites, formed in a littoral environment where the waters were favorable to the multiplication of planktonic foraminifers, Lamellibranchs and Brachiopods. The sedimentological characteristics indicate a sudden retreat from the shore, witnessed by the various regressive elementary sequences. These elementary sequences each begin with a layer of thanatocenosis which would be due to a sudden change of environment, consequence of an important arrival of detrital terrigenous sediments. This terrigenous detrital contribution disrupts each time the physicochemical characteristics of the environment (oxygen deficiency, absence of light, high turbidity). The fauna of these formations exhibits a coniacian affinity. The sequential evolution of the deposit shows a large ravine unconformity on the top of the mega sequence. The composition of the fauna and the sedimentological characteristics confirm the existence of a regressive sedimentation model of the Lower Coniacian age.
\end{abstract}

Keywords: Bivalves, lumachelle, regression, sedimentology, thanatocenosis

\section{INTRODUCTION}

The Congo coastal basin is part of the central segment of the Gulf of Guinea, of the African Atlantic margin, whose evolution is linked to the opening of the South Atlantic during the lower Cretaceous, establishing then the separation of the African and South American continents (Le Pichon and Hayes, 1971; Larson and Ladd, 1973). It stretches from southwest Gabon to northeast Cabinda. According to Belmonte et al. (1965), the structure of the basin is roughly monocline. It shows an alternation of horsts and grabens lying globally NW-SE. These hens and ditches are interspersed with normal, globally oriented NE-SW (Read, 1988). It is organized into three large lithostratigraphic units representative of the three major tectono-sedimentary phases (pre-salt, salt and post-salt) that mark the evolution of the Atlantic margin (Guiraud and Maurin, 1992; Grosdidier et al., 1996; Séranne and Anka, 2005). A saliferous episode testifies to this opening and separates two major periods of sedimentation: a fluvio-lacustrine phase with a pre-salt lacustrine and a salt marine phase. The fluvio-lacustrine phase leads, from the Neocomian to the Aptian, to a first filling (3 to $4000 \mathrm{~m}$ thick) of the rift valleys (Micholet et al., 1970). During the Aptien period, a widespread collapse that can be traced from Angola to Cameroon (Pautot et al., 1973; Reyre, 1966; Reyre, 1984a, 984b; Guiraud and Maurin, 1992) is responsible for the first marine incursion and the deposition of salt series of 300 to $900 \mathrm{~m}$ of thickness. The post-rift series presents two large superimposed units, Aptian to Eocene age aggradation Units and propagation Units of Miocene to the Present Age, separated by a major Oligocene-age erosion of 10 to $15 \mathrm{Ma}$ (Séranne et al., 1992).

The Congo coastal sedimentary basin has been the subject of numerous geological works: Hourcq (1966), Veatch (1951), Riquier (1966), Vennetier (1968), Giresse and Kouyoumontzakis (1971), Giresse (1980, 1982), Giresse et al. (1981a), Giresse and Odin (1973), Giresse and Kouyoumontzakis (1973), Kouyoumontzakis (1979), Giresse and Tchikaya (1975), Cornen et al. (1977), Giresse et al. (1981b), Giresse et al. (1990), M'boro (1980), M'boro et al. (1981), Malounguila-Nganga (1983), Peyrot (1983),

Corresponding Author: Hilaire Elenga, Département de Géologie, Faculté des Sciences et Techniques, Université Marien Ngouabi, Congo

This work is licensed under a Creative Commons Attribution 4.0 International License (URL: http://creativecommons.org/licenses/by/4.0/). 
N'landou (1984), Malounguila-Nganga et al. (1986), Sitou (1987), N'gatse (1989), N'goma (1991), Moukolo (1992), Kitsoukou (1992), Vernet et al. (1996), Mbani (2008) and Malounguila-Nganga et al. (2017). However, Emilianoff and Schneegans (1934) deserve the credit for the first studies that provided information on the sedimentary series along the basin of the Cretaceous age. It has recently been the subject of a detailed study as part of the production of a new 1/200 000 geological map by the France Bureau de Recherche Géologique et Minière (Callec et al., 2015).

This study provides an insight into the evolution of the Senonian paleogeography, as there has been very little scientific work done on this stage by the oil companies. The work was based on two rock outcrops, the Pointe Mvassa and Pointe de Djéno, located south of Pointe-Noire. A comparison with the recent BRGM sections at the same sites allows us to refine our observations and make significant contributions to the paleogeographic reconstruction of the region.

\section{MATERIALS AND METHODS}

Study area: The study area is located in Pointe-Noire city, along the Pointe Djéno, Pointe Mvassa and Pointe Indienne. The Congolese coastal region stretches between $4^{\circ}$ and $5^{\circ}$ south latitude and $11^{\circ}$ and $12^{\circ}$ east longitude. In its western part, the Congolese coastal region opens on a $108 \mathrm{~km}$ sea front. It is SE-NOoriented and includes many bays widely open towards the North. These bays are limited in their southern part by rock formations of very low altitude that constitute the rare outcrops of this low and sandy coast. This study covers two of these outcrops (Fig. 1). Located south of Pointe-Noire, the site of Pointe de Djéno ( $\mathrm{S}$ $04^{\circ} 55^{\prime \prime} 398 "$ "; E $11^{\circ} 55^{\prime} 938^{\prime} ; \pm 3 \mathrm{~m}$ of altitude), is a carbonated discharge of about $5.70 \mathrm{~m}$ thickness, overlain by a sady layer of $2.10 \mathrm{~m}$ thickness layer of sandy. It hasNNE-SSW direction. It has sub-tabular layers without fracturing, of $\mathrm{N} 115^{\circ}$ direction and $4^{\circ} \mathrm{S}$ of dip.

The Pointe Mvassa site is located between S $04^{\circ}$ 55' 401'; E $11^{\circ} 55^{\prime}$ 946"; $\pm 2 \mathrm{~m}$ altitude. The carbonated series studied is sub-tabular, without fracturing, with an $\mathrm{N} 110^{\circ}$ direction and a dip of $4^{\circ} \mathrm{S}$.

Methodology: The field study consisted of a description of each bank of the facies of the various outcrops and the review of the lithological sections. The different facies were described with a focus on lithology, mineralogy, texture, thickness of lithological units, sedimentary structures and paleontological content and finally the review of the lithological sections. In the laboratory, a petrographic and mineralogical study was carried out under a polarizing microscope.

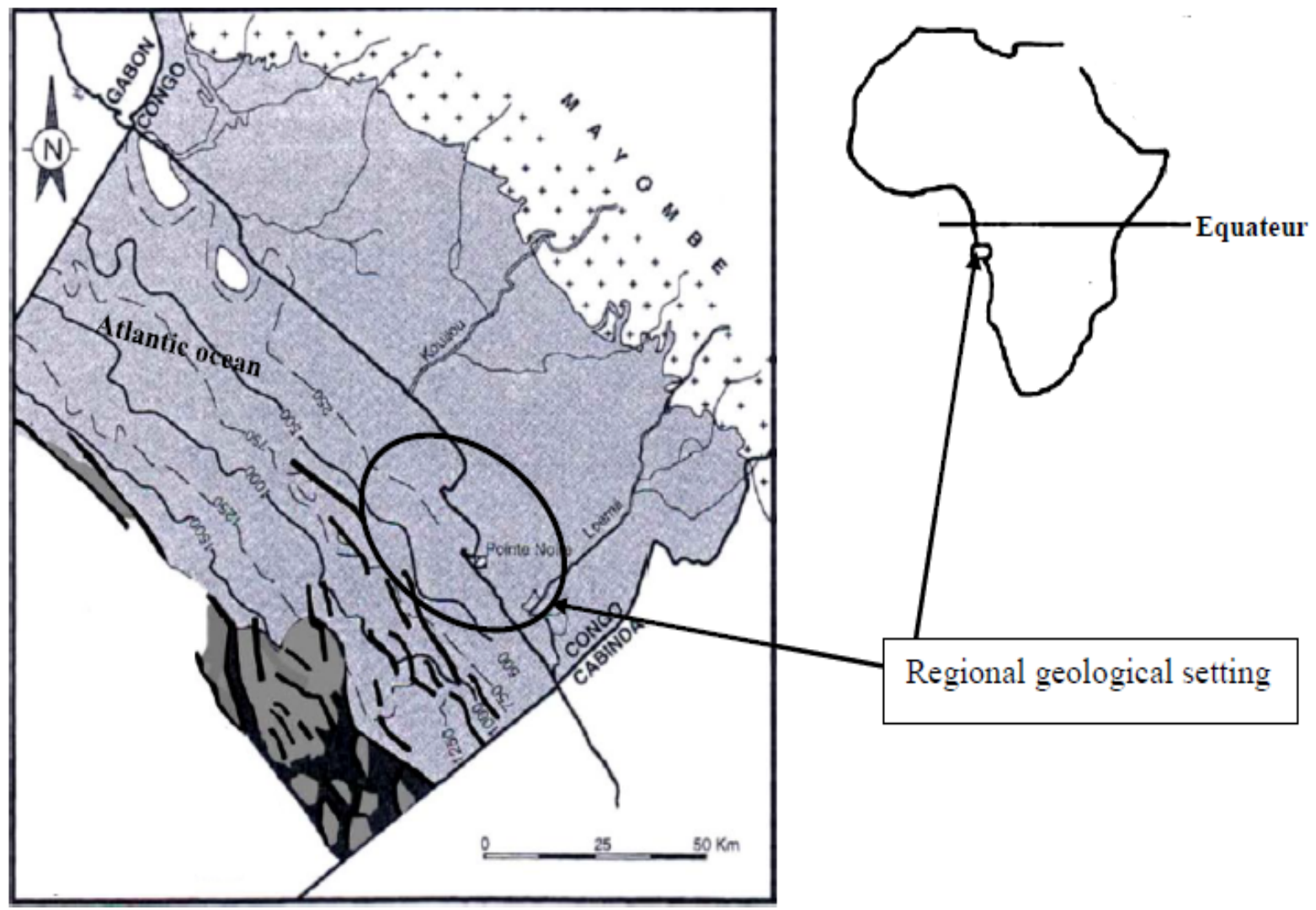

Fig. 1: Location maps (Vernet et al., 1996; modified) 


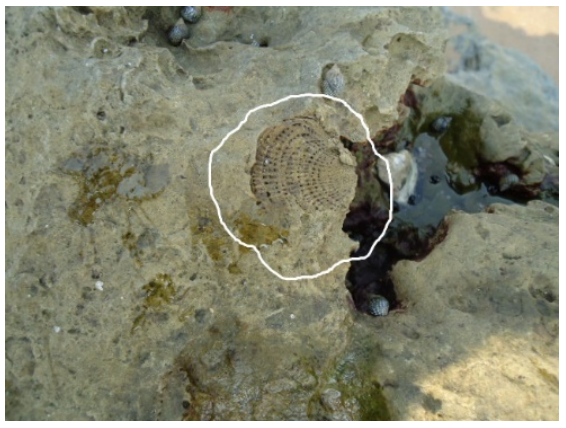

Fig. 2: Mold of a Lamellibranch shell (4 $\mathrm{cm}$ in diameter)

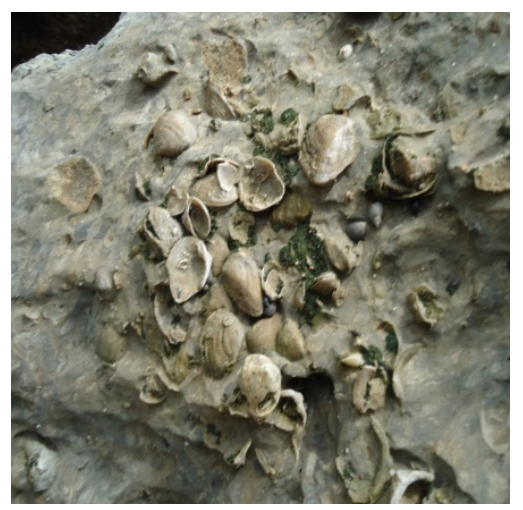

Fig. 3: Brachiopod shell

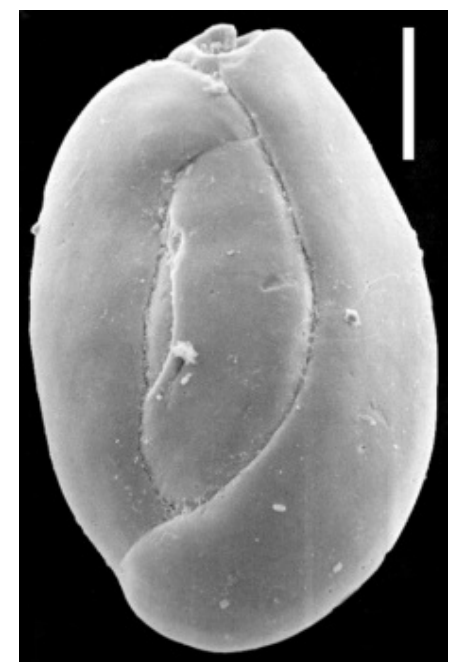

Fig. 4: Quinqueloculina

\section{RESULTS}

Macroscopic facies of the pointe djéno outcrop: In total, 19 facies were identified by indicative macrofacies on the outcrop of Pointe Djéno. At the base, there is a silty dolomite with a cluster of whole Lamellibranch shells which are molded (Fig. 2) on top of one another. This facies is overlain by a thin layer of Lumachelle dolomite with whole shells without any particular orientation. Then comes a bioturbated gray dolomite. Unlike the previous one, this facies is completely devoid of shell material. This bioturbation is interrupted by an alternation between a beige thanatocoenosis-bearing dolomite that includes young Lamellibranch shells and a gray dolomite with broken or even pickled shells.

This alternation ends with a gray dolomite with bioturbation overlain by a beige thanatocoenosisbearing dolomite. After this, a series of massive dolomitic sandstone followed with fossilized lamellibranch molds, beige Lumachelles and thanatocoenosis-bearing dolomites and a dolomitic limestone with large whole fragmented and crushed shells of lamellibranch bivalves. A thin detrital sandyclay terrigenous layer with abundant traces of Kaolinite is deposited. The top part consists of a silicized dolomitic Lumachelle with fragmented and crushed shells. Above this carbonate outcrop, a thick sandbank containing sandy gravel at the base, similar to the sandy gravel of the current foreshore, was deposited. This gravel is overlain by a layer of yellow clayey-sand on which rests an ancient shoal that evolves into a podzol of more than $3 \mathrm{~m}$ thick.

These facies thickness ranges from 5 to $20 \mathrm{~cm}$ and from 95 to $140 \mathrm{~cm}$.

Macroscopic facies of the pointe mvassa outcrop: The outcrop of Pointe Mvassa shows a succession of 10 facies. The organization of the facies is identical to that of Djéno Rocher. A succession of dolomitic sandstone facies is observed, alternating with thanatocoenoses facies. The dolomitic sandstone facies have large mussel shells and Lumachelle shells; mussels and shells are not joined, they are connected by sparite cement associated with quartz and feldspar silts. In addition, the thanatocoenosis feature Lamellibranch shells that have been preserved (fossilized); shells are molded together in a sandstone cement and indicate a symptomatic grainstone texture. All of these facies are 10 to $35 \mathrm{~cm}$ thick.

Macro-paleontological description of the facies: A well-determined form of Brachiopods (Fig. 3), identified as Terebratula, is observed in most samples (Fig. 4) which is equivalent to the species identified by Alméras et al. (2014). This species has small (juvenile specimen) to very large shell with a more or less elongated oval contour. The frontal morphogenesis is as follows: rectimarginate stage, then late and prolonged planoplication that may remain low even in larger specimens. A slightly higher planoplication is most common, creating a dorsal medial flattened area. Large hook, not crested, curved up and hiding the deltidium, large circular foramen, always edged, labiate in the largest specimens.

\section{Microscopic description of facies:}

The djéno rocher facies: The bivalves shell debris of 


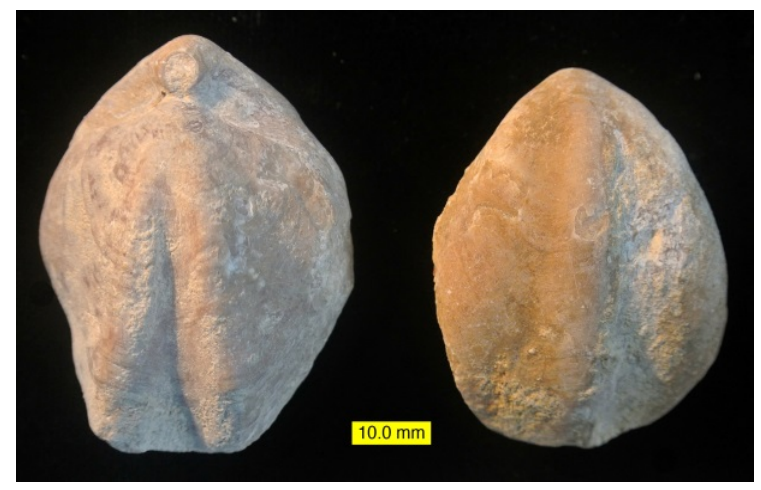

Fig. 5: Terebratula

the rudite class are connected by a carbonate and silt mud rich in quartz and feldspar silts, which are angular to sub-rounded, some micas are also found. Feldspars are predominantly plagioclase and a few microclines.

Bioclasts previously epigenized by calcite are much more visible in unanalyzed polarized light due to the high degree of epigenization, while in analyzed polarized light, they are confused with cement. The voids observed in the shells were filled with detrital (mainly quartz and feldspars).

Biosparudites with fully epigenized bivalve mussels are associated with tube-like epigenized bone debris.

The silty bioclastic micrite is rich in debris of quartz and plagioclase silts that are very angular and a few rare sericites. Bioclasts are essentially foraminifera of the Quinqueloculina type (Fig. 5). In addition, debris from Brachiopods shells are almost non-existent. A few fragments of elongated bone are observed, but they are finely structured in a form of lamellae. Their size exceeds $2 \mathrm{~cm}$.

The pointe mvassa facies: All the slides subjected to microscopic analysis show a silty micrite with quartz and feldspars. These are sub-rounded plagioclases, a more angular quartz and some sea urchin spicules on the detrital. In some slides, the silts are finer and fewer. In other slides, the silts are fine and more numerous. The percentage of silts varies from one blade to another. Voids filled with microcrystalline calcite and a few sea urchin spicules are sometimes observed, as well as facies illustrating the end of a crustacean leg. Some silty micrites have several recrystallization zones without any particular structure. Others are very poor in detrital with a few sea urchin spicules.

\section{Results interpretation:}

Paleofacies: From a lithological point of view, the outcrops of Djéno Rocher and Mvassa have many similarities. For instance, the facies are essentially carbonate. There is an alternation of bioclastic dolomite levels of bioturbated bioclastic dolomite accumulation, with bioclastic dolomites for the creation of young, or mature, Lamellibranch, packed in sparite cement rich in quartz and feldspars silts. This alternation ends with a silty and sandy marl inter-stratum indicating a deepening of the basin and a sudden change in the dynamic conditions of the environment where the waters become less oxygenated and very turbid, causing the reef to be botched. The top level is marked by a very thick level of highly bioturbated and silicified bioclastic dolomite accumulation, by a small level of foreshore-like gravel. Although this level is very developed in Djeno, it is absent in Mvassa (Fig. 6). Its absence at Mvassa is structural in nature because the entire formation is slightly sloping from $2^{\circ}$ to $4^{\circ}$ SouthWest, thus towards the Djéno Point (Callec et al., 2015). This also explains the absence of certain levels in the outcrop of Mvassa.

Paleoenvironments of the deposits: Lamellibranchs are building organisms and form reefs in the shoreface area. The development of these reefs requires a much oxygenated and less turbid water, even though the area is affected by the wave surges. In the concerned area, there is a succession of reefs that develop on shelled silty dolomites where shellfish debris predominantly of Lamellibranchs are connected by a sparite cement rich in quartz and feldspar silts. These reefs are not more than $10 \mathrm{~cm}$ thick. The alternation of large-shell Lamellibranch (mature) reefs and small-shell Lamellibranch (young) reefs indicates a failed reef. This failure can be justified each time by two successive phenomena: Episodic reef displacement in the external shoreface (transition zone) where the waters become less oxygenated (moderate hydrodynamic zone) and inflow of turbid waters very rich in fine detrital (quartz and feldspar silts) favor significant pelitic sedimentation that is not very conducive to the development of the reef. The superposition of the two phenomena causes the brutal death of the Lamellibranch and the failure at each episode of the reef. Finally, the absolute death of this reef is caused by the development of level g (Fig. 6), which consists of a silty and sandy marl that overlies the top level d1 (Fig. 6) of the reef with young Lamellibranch shell. Thus, this result to extensive pelitic sedimentation in the basin and reflects a deepening of this basin. The end of the development this formation is characterized by a return into shoreface to foreshore environment and exceptionally backshore (very high hydrodynamic zone). Here, the reef is highly affected by waves that will favor the accumulation of a very thick lumachelle deposit consisting of Lamellibranch shell debris and which overlies the $\mathrm{g}$ level. This level, being affected by a significant bioturbation, can be considered to have long emerged. However, this justifies the beginning of the withdrawal of the sea level (regression). 


\section{Djeno Rocher}

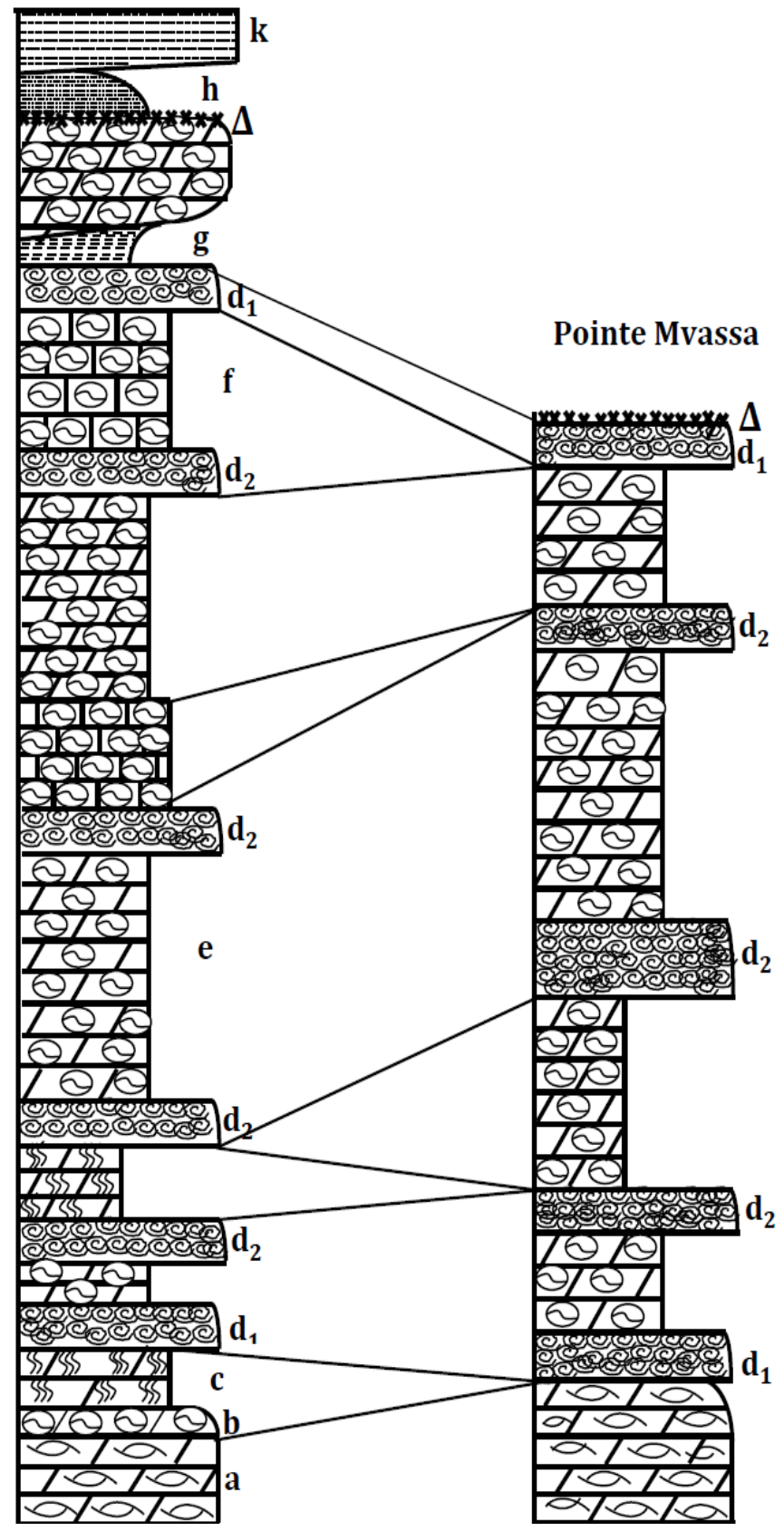

Fig. 6: Lithological correlation of Djéno Rocher and Pointe M'vassa logs

a: Silty Lumachelle dolomite; b: Lumachelle; c: Bioturbated dolomite; d1: Reef with young Lamellibranchs shells; d2: Reef with mature Lamellibranchs shells; e: Massive dolomitic sandstone with large shells (Lumachelle); f: Dolomitic limestone (ancient Lumachelle); g: Marl joint; h: Clayey sandstone; k: Gravelly sand; $\Delta$ : Gully erosion surface

Geodynamic setting and sedimentation: The outcrops of Djéno and Mvassa belong to the Congo coastal basin, which itself forms part of the central Atlantic segment which originated in the Jurassic, precisely in the Neocomian in the Congolese sector. These dolomite outcrops represent the opening of the rift to the sea in the Albian. During this period the Aptian-aged lagoon became a confined sea (transgression), favoring the development of coastal carbonates along the edge and the pelites in the center of the basin. In the TuronianSenonian, a regression linked to the Alpine orogen began. The outcrops of Djeno and Mvassa describe a megasequence of bioclastic dolomites with sparite cement rich in quartz and feldspar silts and the presence 
of botched reefs. The existence of thanatocoenoses with young Lamellibranch shells and the abundance of terrigenous detrital silts in these deposits allow us to highlight the existence of a high-level prism that could be the result of the accumulation of silty debris in the basin from the continent and that obstructs light, thus, causing the premature death of Lamellibranchs. This high-level prism is the expression of the end of the transgression and thus the beginning of a regression. The significant development of a highly bioturbated and silicfied Lumachelle at the top of the sequence confirms that, this deposit has long been emerged, its absence on the top of the Mvassa outcrop allows us to conclude that it has been exposed to erosion for a long time. This deposit expresses the regressive character.

\section{DISCUSSION}

The petrographic, lithological, paleontological studies of the Djéno and Mvassa carbonate deposits show that they are located in supra-tidal, intertidal and subtidal marine domains. Indeed, the variation in the sea level shows a gradual evolution of the deposition environments and characterizes the vertical arrangement of facies. Due to the sudden regressive movement and a high hydrodynamism, some lithological units on the Mvassa outcrop were eroded, leaving hiatus.

Five levels of thanatocoenoses were observed: two levels of shells of fossilized living young Lamellibranchs that ends the levels of Lumachelles and the other three levels of shells of old Lamellibranchs in a living position. The death of the young Lamellibranchs raises several questions about the living conditions of these bivalves or the conditions of sedimentation in the environment. Following the results obtained, the death of the young Lamellibranchs is due to the turbulence of the environment. The Lamellibranchs live in a shallow, oxygenated marine environment with regular salinity. The existence of a luminous contrast with an oxygen deficiency in the marine environment, as a result of a detrital inflow, will lead to the brutal death of the growing Lamellibranchs. Therefore, this very important detrital inflow is a sign of a regression that could be related to the Alpine orogenesis. In fact, the thanatocoenosis of young Lamellibranchs reflects a sudden change in the deepening of the basin, while the thick thanatocoenosis of mature Lamellibranchs marks a stabilization of the sea level.

The microscopic analysis shows that completely epigenized biosparudites with bivalve mussels are associated with unepigenized bone fragments. Moreover, debris from Brachiopods shells are almost non-existent or entirely epigenized and no longer observable under the microscope. Bioclasts were previously epigenized by calcite. These bioclasts are essentially foraminifera of the Quinqueloculina type. It is therefore an ancient carbonate and silty-mud which contains some foraminifera close to the Quinqueloculina type.

The coastal deposits studied characterize the regressive model. This regression continues abruptly. Also, the thanatocoenoses then find themselves in the surge area from which they are reworked by the waves to turn into a shelly-pile. Sometimes this pile is found in the open air as a sandbar and undergoes bioturbation. Finally, the great regression that becomes effective begins. The presence of the very thick level of Lumachelle, which is found in the open air at Djéno Rocher due to the importance of its bioturbation on the one hand and its absence at the top of the Mvassa outcrop on the other hand, perfectly confirms the eroding of this Lumachelle. This regression was thus achieved in several stages, contrary to the transgressive model proposed by Dadet (1969) and supported by the petroleum researchers.

Unlike the Turonian age that was attributed to these carbonate formations by the petroleum researchers, this regression perfectly corresponds to the period of the lower Coniacian which shows a regressive interval. Hirtz (1951) also attributed the Coniacian and Santonian ages to these deposits from malacofauna collected at Djéno Rocher and Pointe Mvassa, as well as Ammonites collected in the Loya and Mvassa quarry. Mbani (2008) and Callec et al. (2015) also attributed the Coniacian age to these deposits. Mbina Moungengui et al. (2008) described the same organisms in the Coniacian formations of the Anguilla series of the Gabonese coastal basin. Since the structure of the basin is monocline, the Turonian-age carbonates would therefore be located deep below the Djéno Rocher carbonates, below the current sea level.

\section{CONCLUSION}

The outcrops of Djéno Rocher and M'vassa are essentially dolomites that have formed in a shallow marine environment where the waters were favorable to the multiplication of Lamellibranchs. These Lamellibranchs built young reefs that were later transformed into shoals under the action of the waves. The thanatocoenosis of young Lamellibranchs reflect a sudden change of the deepening of the basin, while the thick thanatocoenosis of mature Lamellibranchs mark a stabilization of the sea level.

The macroscopic analysis shows a lifestyle-related diagenesis of these organisms giving a grainstone texture on the one hand and a diagenesis linked to a slight landfilling of their living environment resulting in a packstone texture, on the other hand. The evolution of these facies shows a sudden shoreline retreat. Thus, their evidences entail the different regressive elementary sequences that constitute the mega- 
sequence of each discharge. The small regressive elementary sequences and the large gully surface in the top of the two outcrops confirm the regressive model that could be attributed to the Lower Coniacian in accordance with the work of Hirtz (1951), Mbani (2008) and Callec et al. (2015).

Consequently, the paleontological analysis shows a fauna characterized by planktonic (Quinqueloculina), bivalves (Lamellibranchs, Terebratula) and sea urchin spicules. These bivalves of Coniacian affinity correspond to those described by Mbina Moungengui et al. (2008) in the Coniacian formations of the Anguilla series of the Gabonese coastal basin.

In view of the above, the carbonated formations of Djéno rocher and Mvassa along the coast of PointeNoire are of the Coniacian age and describe a regressive model.

\section{ACKNOWLEDGMENT}

We would like to thank the laboratory of the Geological and Mining Research Center (CRGM) which fully funded the research. Our thanks also go to the Geology department of the Faculty of Science and Technology (Marien Ngouabi University) for the corrections and suggestions they made to the manuscript. Our sincere thanks to the reviewers for the remarkable quality of their observations which contributed to the improvement of this study.

\section{REFERENCES}

Alméras, Y., M. Cougnon and P. Fauré, 2014. Les Brachiopodes jurassiques (Terebratulidina). Principaux genres et leur évolution. Les espèces, extensions verticales et répartitions géographiques. Strata, Toulouse, 49: 198.

Belmonte, Y., P. Hirtz and R. Wenger, 1965. The Salt Basins of the Gabon and the Congo (Brazzaville). In: Salt Basins Around Africa. The Institute of Petroleum, G.B.

Callec, Y., E. Lasseur, B. Le Bayon, T. Thiéblemont, J. Fullgraf Gouin, F. Paquet, J. Le Metour, V. Delhaye-Prat, P. Giresse, D.M. MalounguilaNganga and F. Boudzoumou, 2015. Notice Explicative de la feuille Pointe Noire à 1/200 000 . Programme National de Cartographie Géologique. Ministère des Mines et de la Géologie. Dir. Min. et de la Géol., édition BRGM, 2015, pp: 216.

Cornen, G., P. Giresse, G. Koyoumontzakis and G. Moguedet, 1977. La fin de la transgression holocène sur les littoraux atlantiques d'Afrique équatoriale et australe (Gabon, Congo, Angola, Sao Thomé, Annobon) - Rôles eustatiques et néotectoniques. Ass. Sen. Et. Quat. Afr., Dakar, Sénégal, 50: 59-83.
Dadet, P., 1969. Notice explicative. de la carte géologique de la. rép du Congo BIville au, 1/500 OOO. (zone comprise entre les parallèles $2^{\circ}$ et $5^{\circ}$ Sud). Mémoire du BRGM, No. 70.

Emilianoff, G. and D. Schneegans, 1934. La stratigraphie du sénonien dans le bassin du MoyenCongo. C.R. Groupe. Géol. Pétrol. Strasbourg, décembre 1934, 5: 4-5.

Giresse, P., 1980. Carte sédimentologique du plateau continental du Congo. ORSTOM, Notice Explicative No. 85, Editions ORSTOM.

Giresse, P., 1982. Les terrasses alluviales en République Populaire du Congo: Bilan de paléoenvironnements climatiques, morphologiques et préhistoriques. In Ass. Sénégal. Quatern. Afr., Bull. Liaison, Sénégal, 62-63: 113-136.

Giresse, P. and G. Koyoumontzakis, 1971. Géologie du sous-sol du Port de Pointe-Noire et des fonds sousmarins voisins. Ann. Univ., Brazzaville, 7: 97-114.

Giresse, P. and G.S. Odin, 1973. Nature minéralogique et origine des glauconies du plateau continental du Gabon et du Congo. Sedimentology, 20: 457-488.

Giresse, P. and G. Kouyoumontzakis, 1973. Cartographie sédimentologique des plateaux continentaux du Sud du Gabon, du Congo, du Cabinda et du Zaïre. Cah. ORSTOM, Sér. Géol., 5(2): 235-257.

Giresse, P. and C. Tchikaya, 1975. Contribution à la carte géologique de la plate-forme sous-marine congolaise (Mission N.O. Nizery de janvier 1974). Ann. Univ. Brazzaville, 11(C): 23-34.

Giresse, P., F. Jansen and G. Kouyoumontzakis, 1981a. Les fonds de la plate-forme congolaise, le delta sous-marin du fleuve Congo. Bilan de huit ans de recherches sédimentologiques, paléontologiques, géochimiques et géophysiques. Trav. Doc. ORSTOM, 138: 13-45.

Giresse, P., J.F. Jansen, G. Kouyoumontzakis and G. Moguedet, 1981b. Les fonds de la plate-forme congolaise et le delta sous-marin du fleuve Congo. Mém. ORSTOM, Océanographie, 138: 13-46.

Giresse, P., D.M. Malounguila-Nganga and G. Moguedet, 1990. La succession des paléoenvironnements quaternaires des plateformes continentales du Sud du Gabon, du Congo, du Cabinda et du Zaïre (Pléistocène supérieur et Holocène). In paysages quaternaires de l'Afrique centrale atlantique. Editions de l'ORSTOM, pp: 71-77.

Grosdidier, E., E. Braccini, G. Dupont and J.M. Moron, 1996. Biozonation du Crétacé inférieur non marin des bassins du Gabon et du Congo. Géologie de l'Afrique et de l'Atlantique Sud: Actes Colloques Angers 1994, Pau, 1996, pp: 67-82.

Guiraud, R. and J.C. Maurin, 1992. Early cretaceous rifts of western and central Africa: An overview. Tectonophysics, 213: 153-168. 
Hirtz, 1951. Mission du moyen Congo. Rapport de fin de campagne. Soc. Des Pétroles d'Afr. Equat. Française, pp: 84.

Hourcq, V., 1966. Le Bassin Côtier Congolais. In: Reyre-Asga, D. (Ed.), Bassins Sédimentaires du Littoral Africain. 1 ${ }^{\text {ère }}$ Partie: Littoral Atlantique. Symp. New Delhi, pp: 197-206.

Kitsoukou, A., 1992. Etude Géomorphologique du littoral ponténégrin (CONGO): Contribution à l'étude des érosions actuelles du rivage. Thèse de Doctorat de l'université Louis PASTEUR de Strabourg I, pp: 297.

Kouyoumontzakis, G., 1979. La microfaune benthique du plateau continental congolais: Inventaire, répartition, stratigraphie du quaternaire supérieur, rapport avec la sédimentologie. Thèse Doct. Spéc. Marseille, pp: 136.

Larson, R.L. and J.W. Ladd, 1973. Evidence for the opening of the South Atlantic in the early Cretaceous. Nature, 246: 209-212.

Le Pichon, X. and D.E. Hayes, 1971. Marginal offsets, fracture zones, and the early opening of the South Atlantic. J. Geophys. Res., 76: 6283-6293.

Malounguila-Nganga, D.M., 1983. Les environnements sédimentaires des plateformes du Congo et du Gabon au Quaternaire supérieur d'après les données des vibro-carottages. Thèse 3e cycle, Toulouse III (France), pp: 169.

Malounguila-Nganga, D.M., P. Giresse and G. Moguedet, 1986. Histoire sédimentaire de la paléovallée estuarienne du Kouilou (R.P. Congo) pendant le Quaternaire: exemple ouest-africain d'évolution de l'interface Océan-Continent. In Global change in Africa during Quaternary - Past, Present, Future Y, Symposium INQUA Dakar, avril, 1986.

Malounguila-Nganga, D., P. Giresse, M. Boussafir and T. Miyouna, 2017. Late Holocene swampy forest of Loango Bay (Congo). Sedimentary environments and organic matter deposition. J. Afr. Earth Sci., 134: 419-434.

Mbani, J.N., 2008. Micropaléontologie et géochimie organique du bassin côtier congolais au Crétacé supérieur: Paléoécologie des foraminifères, espèces et associations indicatrices des paléoenvironnements des roches mères pétrolières. Thèse de $3^{\text {ème }}$ cycle, Université Paris, pp: 6 .

Mbina Moungengui, M., F. Baudin and M. Guiraud, 2008. Caractérisation et paléoenvironnements des dépôts riches en matière organique de la série de l'Anguille d'âge coniacien-santonien dans le bassin sédimentaire côtier gabonais. Africa Geoscience Review, Special Publication 2008/01, pp: 89-97.

M'boro, R., 1980. Le bassin de Pointe-Noire (Congo) du Sénonien au Néogène. Thèse de doctorat de l'Univ. de Provence, Marseille, 2 Tomes, pp: 336, $35 \mathrm{pl}$.
M'boro, R., R. Anglada and L. Brun, 1981. Le bassin de Pointe-Noire (Congo) du Sénonien supérieur au Néogène (Stratigraphie-Paléogéographie). Cah. Micropal., 4: 73-102.

Micholet, J., E. Mounas and B. Penet, 1970. Le Système du Karroo au Gabon. Proceeding of 2nd Gondwana Symposium, South Africa 1970, Froc. a. Papers, pp: 371-380.

Moukolo, N., 1992. Hydrogéologie du Congo: Le bassin sédimentaire côtier. Document du B.R.G.M. No. 210, Orléan, pp: 59-75.

N'gatse, L.R., 1989. Les ostracodes du post-salifère congolais du Crétacé inférieur au Miocène: systématique, stratigraphie, biogéographie. Thèse de Doctorat de l'Univ. Pierre et Marie Curie (Paris VI), n०89(8): 228.

N'goma, C., 1991. Fluctuations du niveau marin au cours de l'Albien supérieur dans le bassin côtier congolais. Analyse micrographique, géochimique et diagraphique des environnements sédimentaires et diagénétiques. Thèse de Doctorat de 1'Univ. de Bourgogne (Dijon), pp: 373.

N'landou, J.D., 1984. Le gisement maestrichtien de phosphates de Tchivoula (R. P. du Congo), étapes de sédimentogénèse marine, de diagenèse et d'altération. Thèse $3^{\circ}$ cycle, Université Paul Sabatier (Toulouse), pp: 219.

Pautot, G., V. Renard, J. Daniel and J. Dupont, 1973. Morphology, limits, origin, and age of salt layer along South Atlantic African margin1. AAPG Bull., 57(9): 1658-1671.

Peyrot, B., 1983. Interprétation géomorphologique du littoral et de la façade maritime atlantique de la République Populaire du Congo. Trav. Doc. Géogr. Trop., CEGET, 49: 75-79.

Read, A.P.P.A., 1988. Aperçu géologique et pétrolier des bassins du Congo. Rapport de l'association des producteurs de pétrole Africains. Ministère des mines et de l'énergie de la RPC (mai, 1988), pp: $38+$ annexes.

Reyre, D., 1966. Particularités géologiques des bassins côtiers de l'ouest Africain. Essai de récapitulation. In: Reyre, D. (Ed.), Bassins sédimentaires du littoral africain, première partie, littoral atlantique. Ass. Serv. géol. Afr., Paris, pp: 253-304.

Reyre, D., 1984a. Caractères pétroliers et évolution géologique d'une marge passive. Le cas du bassin Bas Congo-Gabon. Bull. Centre. Rech. Explor. Prod., ELF-Aquitaine, 8(2): 303-332.

Reyre, D., 1984b. Remarque sur l'origine et l'évolution des bassins sédimentaires africains de la Côte Atlantique. Bull. Soc. Géol., France, Paris, Sér. 7, 26(6): 1041-1059.

Riquier, J., 1966. Notes sur l'érosion en cirque au Congo. ORSTOM WC, 137 services pédologiques. B/ville, pp: 6 . 
Séranne, M. and Z. Anka, 2005. South Atlantic continental margins of Africa: A comparison of the tectonic vs climate interplay on the evolution of equatorial west Africa and SW Africa margins. J. Afr. Earth Sci., 43: 283-300.

Séranne, M., M. Seguret and M. Fauchier, 1992. Seismic upper-wints and post-rift evolution of the continental passive margin of southern Gabon. Bull. Soc. Géol. Fr., 163(2): 135-146.

Sitou, L., 1987. Etude des littoraux en milieu tropical et humide: Approche méthodologique. Mémoire de D.E.A., U.L.P. Strasbourg, Institut de Géographie, pp: 113.
Veatch, A.C., 1951. Evolution of the Congo basin. Bull. Géol. Soc. Am. Mem., No. 3.

Vennetier, P., 1968. Pointe-Noire et la façade maritime du Congo B/ville. Mémoire ORSTOM, 26: 458.

Vernet, R., C. Assoua-Wande, L. Massamba and P. Sorriaux, 1996. Paléogéographie du Crétacé (Albien-Maastrichtien du bassin côtier congolais). Géologie de l'Afrique et de l'Atlantique sud: Actes colloques Angers 1994, pp: 39-55. 